\title{
Faith and South African realities in practising forgiveness
}

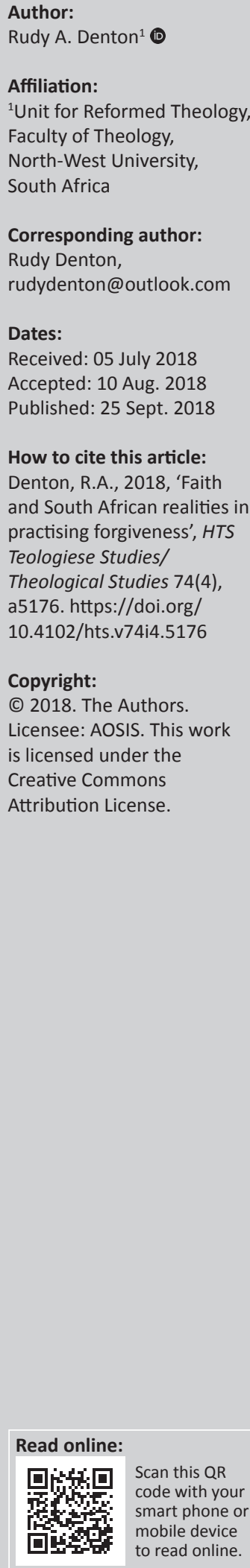

The invocation and necessity of a forgiveness process have become complicated and multifaceted within the South African society with its realities of crime, poverty, racism, injustice and abuse. The rhythms of forgiveness compel us to identify our present situation. Individuals, as well as larger social groups, should begin to reflect on the importance of forgiveness to deal with transgression, violence, revenge and bitterness. I suggest that forgiveness within the Christian doctrine needs to be situated and embodied in specific habits and practices of Christian life within the South African society. In response, people in South Africa are called to remember past transgressions while pursuing the repairing and healing of the brokenness and separations in relationships by embodying forgiveness. It directs the importance of the Church's prophetic task to proclaim the boundless gift of a constructive and transformative relationship with God, one another and God's creation. Practising forgiveness includes a process of seeking to embody Christian forgiveness that involves the transformation of people's lives, their world and their capability to restore communion within the field of social relations.

\section{Introduction}

People often experience injustice, which can cause intense pain, humiliation and deep wounds. Injustice triggers the need for revenge and retaliation and forgiveness is one of the first steps to healing when people attempt to move on with their lives after a painful or distressing experience. Analysing a theological reflection on forgiveness predominantly deals with glitches of inequalities, conflicts in power and control, unremorseful wrongdoers and the related interaction between judgment and grace, retribution and punishment, accountability and repentance. Forgiveness that functions within the sphere of theological reflection could activate the reconciliation and restoration of a community within the field of social relations. Jones (1995:xii) explored the approach in which forgiveness can be personified in societies and communities troubled by hostile divisions in interpersonal conflict and violence. Jones (1995:5) emphasises that 'people are mistaken if they think of Christian forgiveness primarily as absolution from guilt; the purpose of forgiveness is the restoration of communion, the reconciliation of brokenness'.

Forgiveness is frequently inclined to be either too easy or too difficult (cf. Jones 1995:6). On the one hand, the concept of forgiveness views forgiveness to entail a move made for the well-being of the forgiver. An inexpensive account of forgiveness may empower people in the short term to 'feel' better or to 'cope' with their situation, without compelling them to amend or transform the patterns of their caring about the quality of human relations, and can only create the illusion and masking of restored relationships. On the other hand, forgiveness is frequently intensified and challenged by ideas that violence is the only effective force to respond to injustice. Regarding such a view, Jones (1995) argues that:

The necessity of violence can be either celebrated or mourned; further, people can respond either by seeking to dominate through the deployment of violence, or they can seek to foster community by minimizing the force and effects of violence. (p. 6)

In both cases, none of these viewpoints are appropriate practices for a comprehensive theological framework in exploring and reconstructing a personified Christian forgiveness process. Forgiveness should not be portrayed as an attitude of non-violence to respond to injustice or an emotional feeling to reach personal well-being; it must be practised and embodied (personified) by the interrelationship of judgment, retribution and grace, and repentance and forgiveness. Forgiveness can be kept in balance with justice in the understanding that humans (victim and offender) are redeemed and pardoned sinners through Christ (Denton 2016:1). On such a view, Jones (1995:16) sheds light on the theological interaction in relation to repentance and God's 
forgiving and reconciling grace: 'In one sense repentance prepares us to receive God's grace, but in another, more profound sense we discover through our repentance that God's grace has already found us'.

Individuals as well as larger social groups ought to embody (personify) the practices of forgiveness and repentance in specific social and political situations. As Christians, they should begin to reflect on the importance of forgiveness to deal with transgression, violence, revenge and bitterness. This article reflects the Christian doctrine of the Trinitarian God to be the fundamental theological framework and description of an applicable understanding of a forgiveness process in the present-day South African environment. The central theoretical argument in this article is that a practising forgiveness process (framework) in present-day South Africa can indeed be a constructive form of interconnectedness between ubuntu principles and the embodiment (personification) of forgiveness.

To illuminate the argument, this article focuses firstly on faith and South African realities; then, in light of this background, it provides a brief hermeneutical overview on human dignity, depravity and redemption. Next, attention is given to a hermeneutical overview on forgiveness and lastly to an exposition of views toward a contextual approach of a forgiveness process in present-day South Africa and what it could mean for community and societal development, as a basis for further discussion.

\section{Faith and South African realities}

Religion in South Africa remains an essential shared element of community interaction. Statistics South Africa's Community Survey 2016 indicates that the population size of South Africa has increased from 51.77 million in 2011 to 55.65 million in 2016 (Statistics South Africa 2016:19). A wide variety of this population acknowledges and confesses some religious affiliation and faith practice in South Africa (cf. Joubert \& Grobler 2013:1; Pew Research Center 2010b). Brodie $^{1}$ (2016) revealed the majority of South Africans (85.7\%) to be self-identified Christians (cf. Statistics South Africa 2012:39). The Pew Research Center (2010a) also indicated in their South Africa survey that $79 \%$ of Christians emphasise the importance of religion in their lives and $86 \%$ are confident of their faith in God. Masci ${ }^{2}$ (2015), from the Pew Research study, argues that by 2050 the percentage of Christians in the world is projected to stay unchanged, but the percentage of Christians in sub-Saharan Africa will increase dramatically while Europe's current percentage of Christians will continue to decline. In light of the above information, South Africa can be regarded as a growing religious country with strong religious beliefs and practices. According to the Pew Forum on Religion and Public Life (Bardos, Burns \& James 2009), South Africa's government also imposes low restrictions on religion, confirming Sections 9(2), 15 and 31 of the Constitution

1.Nechama Brodie is head of TRi Facts, the research and training division of Africa Check.

2.David Masci is a senior writer and editor focusing on religion at Pew Research Centre. of South Africa (South Africa, Constitution of South Africa 1996). This provides for citizens to have 'freedom of expression and association with regard to their religious beliefs' (cf. Strauss 2015:4; Van Wyk 2014:8).

As we listen to wounded people's injury and pain, we should realise that experiences of the past cannot be left as 'bygones be bygones, forgive and forget'. Transgression and offending violations created humiliation and injustices even though the persistently demanding socio-political and economic challenges seem to flood our present-day discourses. The invocation and necessity of a forgiveness process have become complicated and multifaceted within the South African society with its realities of violence-driven problem areas. The following topics can be recognised as violencedriven problem areas in South Africa: injustice, crime, tribalism, racism, xenophobia, discrimination against minorities and vulnerable people, sexism, immorality, hate speech, poverty, corruption, poor service delivery, land reform, human trafficking, child molesting, rape, domestic violence, militarisation, neo-liberalism with a market-driven economy, the exploitation of the poor and so on (Duncan 2014:6; McAllister 2009:8; Mwambazambi \& Banza 2014:1-9; Thesnaar 2014:1; Van Wyk \& Vorster 2012:6; Vorster 2014:1-8, 2015:5). Thesnaar (2014:2) argues that violence 'is a reality within the South African society and it has a devastating effect on victims, perpetrators and society at large'. Vorster (2007:40) described violence as 'a disease that effects the whole creation of God'.

In light of the violence-driven problem areas, persistently demanding socio-political and economic challenges and encounters, which the Christian community has to solve, the question many people ask, according to Mashua ${ }^{3}$ (2016), is: 'How can we restore dignity where it has been lost and address the systemic injustices of the past that still live with us today?' In an attempt to answer the question it is crucial for the Christian community and churches to use their prophetic calling through preaching and teaching, as well as the involvement of Christians in society, to address the violence-driven problem areas in modern-day South Africa. Barry (2009:373) offers a description of life in a Christian community that is committed to the spiritual and moral formation of society and argues that to live in the Christian community is to:

- live in mutual accountability, confession and forgiveness

- accept others' and our own brokenness as spiritual gifts

- be formed in and through worship and prayer (liturgy)

- live in gratitude, generosity and hospitality and to discover that hospitality (the gift of giving sacred space to others) is the gift of healing

- live with Jesus at the centre and at the margins.

According to this description, life in a Christian community entails the discovering of vulnerability that calls believers 'to

3.Mahlatse Winston Mashua is the director of the RZIM Zacharias Trust South Africa and is part of the organisation's speaking team. 
be a healing, reconciling, restoring, transformed, and transforming community' (Barry 2009:373). The Christian community's responsibility inevitably requires a hermeneutical overview on human dignity, depravity and redemption in communion with God.

\section{Hermeneutical overview of human dignity, depravity and redemption}

The Bible serves as the indispensable guide and source to enable people to make behavioural changes and 'to live in a peaceful relationship with God and others' (cf. Denton 2014a:4; Roberts \& Watson 2010:166). The Bible defines people as a unit of body, mind and soul with physical and emotional needs (cf. Dt 6:5; Lk 10:27; Denton 2014a:5). To do research on forgiveness practices is to 'engage the narrative of the Triune God's creative and re-creative work as Father, Son and Spirit' (Jones 1995:163) with the Christian reflection on the nature and purpose of human life, which should be viewed in relation to the Triune God (Koopman 2015:630). From this viewpoint forgiveness practices involve the Bible as God's divinely inspired Word, as interpreted in the Christian creeds and reformed confessions' (Denton 2014a:4; cf. Van de Beek 2012:311).

\section{Human dignity}

First of all, human beings are created to live with a purpose and destiny in life as a part of God's peace, friendship and goodness in creation (cf. Breed 2015:2; Vorster 2001:9, 2010:200). God created man in his image, and this creational principle emphasised human beings' worthiness and human dignity in creation (Vorster 2010:199). 'Human dignity is a status that God awards human beings by creating them as imago Dei' (Van Wyk \& Vorster 2012:6). The imago Dei is all about humans created in a relational context connecting them to God, one another and God's creation. As a result, humans are agents and 'representatives of God in this world to care for his work as stewards' (Vorster 2010:200). The imago Dei has to manifest in the comprehensive existence of human beings and not only in a small number of human features or characteristics. The extensiveness of dignity lies in the relational context of humankind, which allows humans to be representatives of God in the world and stewards of creation (cf. Vorster 2007:19). Therefore, to wrong someone means to damage the image of God and treat people with disgrace in 'a demeaning or humiliating way, unworthy of our fair and good treatment' (cf. Jirsa 2004:21).

\section{Human depravity}

Even though human beings are created in the image of God (imago Dei), they rejected the intended communion with God (cf. Gl 5:16-17; Col 2:13-14) and fell into a cycle of brokenness, disorder and sinfulness (cf. Breed 2015:2; Vorster 2001:9). In the concept of human dignity, sin and depravity reflect the unavoidable systems and networks of violence and destruction that separate and isolate people from God, one another and God's creation (Vorster 2001:9, 2011:44). The Fall tarnished the perfect flawlessness of creation and disturbed and disrupted the equilibrium of relations that have been established by the imago Dei. Vorster (2010:200) states: 'Due to the fall of Adam humankind lost its free will and any capability to rectify its destitute state'. As a consequence of this disturbed equilibrium of relationships, humankind alienated itself from God and one another.

\section{Human redemption}

Despite human sin God's gracious love intervenes in the reconciliation of sin by means of costly forgiveness. Jesus' death is accepted as a complete once-and-for-all sacrifice and judgment of grace (Col 2:13-14; Heb 10:12; cf. Strauss 2015:4). God's forgiveness is decisively pronounced in the incarnation, life, cross, death, resurrection and ascension of Christ to restore the peaceable, self-giving communion with God (cf. Bash 2007:147; Koopman 2015:631). To reveal the identity of the Triune God, Jesus sacrificed his life (Phlp 2:5-8) and illustrated unselfish, humble love at the centre of Christianity and initiated salvation for humans. Denton (2014a:5) states that the 'theological interpretation and underlying framework of a Christ-centred life are that the Christian's hope and trust is based on the death and resurrection of Jesus Christ' through which humans are forgiven by God (Eph 2:4-5). When Jesus died for the reconciliation of humans' $\sin$, he paid the debt and took sin upon him (Rm 3:24-25; Eph 5:2; Col 2:13-14; Heb 7:26-27; 1 Jn 2:2). 'He suffers the pain of those who stand up to unjust social systems, even to the point of torture and execution' (Osmer 2008:137). In the power of Jesus Christ's death and resurrection God's justice was satisfied (2 Cor 5:18; cf. Bash 2011:loc.1355; Vorster 2011:48).

The response of God to the sinful nature of humanity is revealed in salvation and reconciliation through Jesus Christ to express God's mercy and faithfulness (cf. Denton 2014a:5; Jn 3:16; Eph 2:14-19). Van Wyk and Vorster (2012:6) argue that 'although sin deforms the human being it does not obliterate the imago Dei because God upholds the dignity of the human being despite sin'. The imago Dei guides people to search for salvation and liberation (redemption) by means of repentance and forgiveness: 'This doctrine says that in a world of suffering and hardship, people can achieve peace by respecting human dignity, seeking the kingdom of God and embodying forgiveness' (Vorster 2010:210). Forgiveness is an indispensable and vital practice for bringing restorative healing and reconciliation into the heart of violence and destruction.

\section{Hermeneutical overview of forgiveness}

Despite their created purpose for communion, human beings seek to secure their lives on continuous competitive desires at the expense of others that make it difficult to escape the repeated cycles of violence and counter-violence. People who suffered or continue to suffer severe injustice may have to struggle throughout their lives to give expression to anger or bitterness but not be overcome by it. This issue, not to be overcome by it, needs to be more carefully and wisely positioned within the Christian doctrine of the Trinitarian identification of God as an explanation for forgiveness (cf. McIlroy 2008:14). 
The fundamental principle of Christian forgiveness entails God's gracious love, redemption and reconciliation through Jesus Christ, and the appeal to repentance in order for Christians to live in their community and society as forgiven, redeemed and reconciled people. The reconciliation with God restores relationships between humans and humans, and humankind and creation. On no account should boundaries obstruct the restored relationship where Christians are called and commanded (cf. Mt 6:14; Col 3:13; Eph 4:29-32) to forgive and love one another, even their enemies (Vorster 2011:50).

In response to God's love and forgiveness of sin Christians are called to express forgiveness and communion with others through well-defined conducts put into practice. Jesus personifies the relationship between God's forgiveness and the dynamics of interpersonal forgiveness. Christians are enabled by Jesus' forgiving love to forgive others because we learn to understand ourselves as sinners who have been forgiven (Denton 2016:2). Forgiveness, understood in the light of the crucified and risen Christ, is the antithesis of a painful and out-of-control present and a counteractive alternative to hopelessness and despair. In Tutu's (1999:31) view, forgiveness is the best self-sacrificing way to uphold humanity, even in adverse situations.

\section{The development process in forgiveness}

Although forgiveness is a preparation of accepting that injustice occurred, it is possible to make peace and reconcile with the pain of the past but not with the physical and emotional violation of the offender (cf. Denton 2016:2; Worthington, Greer \& Lin 2011:213). Continuing to hold long-living fantasies of revenge and ruminate on wounded memories can act as a barrier to forgiveness. A change toward forgiveness means to remember past transgressions but to pursue the repairing and healing of the brokenness and separations in relationships (Tutu 1999:5). Understanding forgiveness from a Christian point of view is a process based on divine mercy, not justice facing another's (or others') injustice (Enright 2011:6). As Bonhoeffer (1995:285) put it, 'Christ made peace with us while we were yet enemies. He made peace with all our enemies too, on the cross. Let us bear witness to this peace to all'. Such a change and development process should occur with theological and ethical principles (cf. 1 Cor 12:1-11) through the reflection and imitation of God's action in Christ and the pneumatological dynamics of the Holy Spirit.

The psychological and moral impact of injustice could impose long-term negative consequences because moral dilemmas and ethical conflicts are an integral part of the social reality of injustice (cf. Bash 2011:loc.134). Forgiveness has a positive effect on a person's moral, physical, emotional and spiritual health (cf. Minirth \& Meier 2007:153). Enright (2011:8) argues that 'forgiveness is a moral virtue, unconditionally expressed as an act of mercy toward those who have acted unjustly toward the forgiver'. When people forgive, they are no longer 'prisoners of their own emotions of anger, hatred and bitterness' (cf. Denton 2014b:16; Malcolm 2008:283).

Injured people's worldview can change when they view the world and their circumstances as unfair and unjust (cf. Worthington 2009:28). Anger, blame and revenge appear to be the most important emotional obstacles in exploring the process of forgiving injustice (cf. Macaskill 2008:49-53). Violence often seems unavoidable because of the personal, social and political conditions in which people are forced to live with the effects of violence and destruction. Where violence seems to be an alternative, forgiveness points forward and provides the possibility and opportunity of a new life, of escaping and breaking apart destructive cycles of transgression, violence, revenge and bitterness created by $\sin$. The introduction to John's gospel (Jn 1:5) specifies that the darkness has not overcome the light. Violence, revenge and retaliation are not acceptable as part of God's intended peace, friendship and goodness in Creation. God forgave (Rm 5:10) and through kindness, compassion, humility, gentleness and patience (Col 3:12-13) people should also forgive (Hägerland 2014:104). In a world of deep-rooted conflict forgiveness is a way to act with non-violence, and more importantly offers a personified way of life at the very heart of Christian theology. Hunt (2013:16-17) describes in the following three points what it means to forgive others:

- To forgive means to release your resentment toward your offender. This implies that you need to release your right

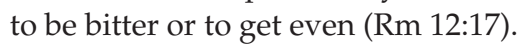

- To forgive is to release your rights regarding the offense. This implies that you release your right to dwell on the offense, to hold on to the offense or dwell in the past (Pr 17:9).

- To forgive is to reflect the character of Christ. Just as God is willing to forgive us, we are called to forgive others. This implies that you extend mercy, give a gift of grace, and set the offender free (Mt 6:12).

\section{Judgment and grace, repentance and forgiveness}

Without justice offenders can avoid responsibilities and create more unjust relationships, potentially damaging interpersonal relationships in society (Denton 2016:2). However, Christians are called to love their enemies, trusting that this love might produce repentance and eventually reconciliation, at the same time leaving the final judgment regarding God's eschatological justice where it belongs, in the hands of God (cf. Rm 12:9-21; Jones 1995:258). By example, Jesus forgave people (e.g., Mt 9:2; Mk 2:5; Lk 5:20) while praying to God to forgive those who were crucifying him (Bash 2011:loc. 316; Worthington 2009:83). Believers are assured that God will bring about retribution on their enemies through an eschatological judgment (cf. Rm 12:9-21).

Even this call, as part of the way of life of forgiveness, may involve an excessively difficult struggle, particularly in relation to the importance of accountability and punishment (cf. Jirsa 2004:18). 'Forgiveness is based on God's forgiveness, while humans tend to both forgive and also pursue justice 
without excusing injustice' (Denton 2016:1). Social justice involves various people with diverse perspectives that need to be taken into account, because people in groups are also independent and often pursue taking justice into their own hands. Offenders' social injustice can intensify the victims' injustice gap, thus making the cycle of violence and retaliation more likely to intensify. Often social groups can take divine justice out of God's hands and assertively act through revenge attacks, honour crimes, bloodthirsty killings and dreadful militia atrocities (Denton 2016:2). Jirsa (2004) highlights that:

If a victim has suffered extreme humiliation, it is hard to forgive even to [sic] a repentant wrongdoer. The burden of the past wrong is simply so big that the victim cannot forswear it without losing face and his moral dignity. (p. 22)

Believers are not permitted to sin but must fight against anger and revenge - including the desire to settle scores with their enemies, which can escalate into hatred with a persistent desire for their destruction. Levinas (2000:20) insists that there is a 'horizontal' dimension to forgiveness among human beings that must precede, or is at least indispensable to, any 'vertical' forgiveness from God. Christians are called to love and forgive their enemies (as children of God created imago Dei) because that is what they have experienced from God. God requires forgiveness (Mt 6:12; 14-15; Lk 6:37-38), and people are accountable if they do not forgive (Denton 2016:1). Christians ought to give up the desire for retaliation and have that desire transformed by God's Spirit into the desire for love and wishing the other person well. Christians can forgive painful or traumatic offences because 'they are responding in gratitude to God's mercy, loving-kindness and forgiveness through Jesus' death on the cross' (Denton 2016:1).

Forgiveness and justice can be kept in balance with the understanding that humans (victim and offender) are redeemed and pardoned sinners through Christ (Denton 2016:2). Christian believers can pursue just forgiveness in relational contexts while keeping the distinction between experiences of just forgiveness, within the context of sin and redemption, without excusing injustice. Christians do not forgive because it is easy; they forgive because they reveal their gratitude by responding to God's mercy, love and forgiveness (Denton 2016:2). By prophetically calling their enemies to account they can show them an alternative way of life. The path of forgiveness, which aims at reconciliation, requires a plea that enemies become accountable, ask forgiveness and take responsibility for their actions. Osmer described prophetic judgment as the activity of 'seeking God's guidance amid the circumstances, events, and decisions of life' and discerning what ought to be done 'to make decisions and settle disputes in the community' (Osmer 2008:137).

Grounded on what God has done, Thesnaar (2014:7) argued that 'we need to embody reconciliation and peace by, amongst others, respecting the human dignity of all involved in the conflict, especially the "other," and emphasising justice and not revenge'. The Holy Spirit guides and enables human transformation through particular practices within the interfaces concerning judgment and grace, repentance and forgiveness (cf. Rm 12:9-21; Vorster 2011:51). In this manner the Spirit guides Christians to recognise the tempting practices to have 'grace without judgment or judgment without grace, to have forgiveness without repentance or repentance without forgiveness' (Jones 1995:136). Christ's particular judgment of grace induces Christians' repentance as a component of God's forgiveness (cf. Koopman 2015:634). The Spirit also guides Christians as they search to discern appropriate practices to embody and characterise Christ in particular circumstances and situations they face (Vorster 2001:13).

\section{Judgment and grace}

Without judgment, grace merely becomes 'cheap grace' and brings about no transformation; and without grace, judgment often turns out to be the modus operandi to keep others accountable in order to maintain cycles of violence, which could even escalate. Judgment aims at grace, as a form of judgment, which is an essential prerequisite of God's forgiveness that brings about transformation when the recipients of forgiveness consequently comply with calls for repentance. To put it in a nutshell, God's forgiveness and judgment of grace require and enable a daily life of repentance in the context of the relationship with God, the self and others.

\section{Repentance and forgiveness}

Repentance and forgiveness are essential building blocks to a Christian way of life. Repentance includes the importance of a judgment of grace on the self and others, which means that forgiveness can never be cheap and reconciliation not superficial (cf. Smith 2007:322). God's forgiveness and reconciling love, marked by the incarnation, life, crucifixion, death and resurrection of Christ, is a judgment of grace that calls for Christians' repentance. Christ's sacrificial death and reconciliation make self-knowledge, self-denial and repentance possible. Repentance is one of the gifts of the Spirit that allows people to confess their sins as a prelude to forgiveness (1 Jn 1:9-10; Vorster 2011:51). To forgive could be to give a 'moral' gift or to release and let go of anger, bitterness and the thirst for revenge (Bash 2011:loc. 2854).

\section{Views towards a contextual approach of a forgiveness process}

The rhythms of forgiveness compel us to recognise our present situation. One might expect Christians in South Africa to advocate the importance of forgiveness, but often they are particularly the ones arguing and demanding punishment, justice and retribution. From this contextual approach, forgiveness has the ability to activate a creative process of practical theological interpretation which should, according to Osmer (2008:17), draw attention to the contextual 'web of life in which ministry takes place ... in terms of interconnections, relationships, and systems'. A practising forgiveness process should make a significant contribution to the praxis of practical theology in that it should convey the 
interconnectedness between theory and practice and deal with complex challenges in the modern-day community and social order and settings of South Africa.

Forgiveness can motivate a process to rebuild and regain the dignity of human beings. However, it poses a challenge to society when those who are powerful take advantage and utilise forgiveness as a weapon to keep their subjects oppressed and powerless, or when the lack of repentance by offenders indicates that offences and violations will persist or perhaps even become aggravated. Ransley and Spy (2004:15) and Denton (2016:1-2) indicate that the practical goal of forgiveness is 'to imitate God, to fulfil one's religious duty, to seek God's forgiveness, to follow the path of righteousness, and to repair the relationship with God, the self and others'.

Forgiveness is a process and not a 'once and for all' act (Bash 2011:loc.1332). Emmons (2006:75) describes forgiveness as a 'spiritual process and development that has emotionregulating properties'. It always happens inside a storm of complex love and hate emotions. Forgiveness is seen as a 'slowly developing process where accumulated anger has developed a desire for justice and revenge but gradually discharge [sic] through a healing process and a sense of empathy towards the offender' (cf. Denton 2014b:11).

In the expression of sin and brokenness, deeply embedded in our South African lives and our structures, Christians are bound to admit the unavoidability of violence in their personal, social and political lives (cf. Jones 1995:78). This acknowledgement can lead to a diversity of normative judgments, stretching from approval of violent behaviour to a moral-ethical denial to approve violence, rather seeking to diminish destructive, violent behaviour. Even if Christians reject violence and advocate forgiveness, they cannot ignore the importance of people's feelings of resentment and desires for revenge or retributive punishment.

\section{Forgiveness in the community and society}

A forgiveness process that is merged into the ubuntu mindset could positively contribute to the modern-day South African community and society. The idealisation of an African soul inclined to forgiveness and communal life blend in the principle of ubuntu.

\section{The phenomenon and conceptualisation of ubuntu}

The following question should be asked when we examine the comprehensive African worldview of ubuntu: What role can ubuntu play in a practising forgiveness process in modern-day South Africa? The most useful description of ubuntu for our purposes is that 'a person is a person because of others' (Breed \& Semenya 2015:2). Kwamwangamalu and Nkonko (1999:27) referred to it as a communally grounded mindset where the well-being of the group is superior to the well-being of a single individual in the group. According to
Matolino and Kwindingwi (2013:198), ubuntu is deep-rooted 'in the search for identity and human dignity'. Broodryk (2002:26) and Chuwa (2014:13) describe it as a comprehensive African worldview based on the core values of intense compassion, humanness, sharing, caring, respect and associated values, ensuring a happy and qualitative human community life in a spirit of the family. According to McAllister (2009:4), ubuntu turns out to be the spiritual foundation of life itself; it is a construction and as such part of an identity-making process'. Hailey (2008:7) concurs and states that ubuntu 'is about developing your "fullness of being" through your relatedness and relationship with others'. Mle and Maclean (2011:1378) explored the issue further and indicated that the concept of ubuntu embodies treating people as human beings with compassion and respect for others. Chuwa (2014:13) highlights that: 'Each member of the community and the community as a whole must guarantee the promotion and protection of life by specifying or ordaining ethics and morality'. Louw (2001:6) indicated that the aim of this kind of spirituality of ubuntu is to provide harmony in interpersonal relationships: 'I am because we are; I can only be a person through others'.

\section{The spirit of ubuntu}

Chuwa (2014:6) emphasises that 'in "ubuntu"-culture every human being is entitled to basic human rights'. Though, 'personal human rights are subordinate to, and dependent on, the fundamental community interests and wellbeing of the society' (Vorster 2015:4). Even if an individual has undeniable human rights, it is the community that recognises those rights (Udeani 2008:68). However, ubuntu is not the same as socialism 'in the sense that it does not enforce equal distribution of wealth, it does not tolerate disproportionate economic inequality' (Chuwa 2014:36). To emphasise caring as an important pillar in the ubuntu worldview, Chuwa (2014:101) indicates that it is inconceivable to collect excessive wealth while fellow humans are in dire need'. This connectedness 'would recognise a moral imperative and accountability beyond human self-interest and manipulation' (De Gruchy 2011:2).

\section{The need to equip Christians for the ubuntu challenge}

Ubuntu can be the foundation of encouragement to assist the embodiment (personification) and practice of forgiveness to heal the painful and traumatic experiences of the past. The 'dynamic and often unpredictable motion between transgression, apology, forgiveness and reconciliation' makes it possible to move forward 'without forgetting the past, but also without remaining stuck in the past' (Komesaroff, Kath \& James 2011:236). The basic principle of change is that the remembering and knowledge of the experienced reality, injustices or transgressions would be the best antidote against repetition. Tutu indicates that 'those who forget the past are doomed to repeat it' (Tutu 1999:31).

In this view, the idea of an African renaissance (with Christian and cultural values) could be effective if Christians adopt the 
interconnectedness between the ubuntu principles and the embodiment (personification) of forgiveness. Breed and Semenya (2015) describe the interconnectedness between ubuntu and forgiveness as follows:

\footnotetext{
... 'ubuntu' calls for peace and reconciliation. It propels the idea of forgiveness and, moreover with its social value of compassion, helps one not to engage in any form of revenge. (p. 5)
}

If ubuntu has shown that it has been effectively functional to numerous levels of justice, politics and conflict resolutions, it gives considerable confidence when considering an application to forgiveness practices. The communally grounded mindset of ubuntu challenges contradictions and ubiquitous conflicts currently experienced in the socialpolitical environment of South Africa. The question is whether ubuntu can encourage Christians to endorse and continue forgiveness practices. Unfortunately, there are various inconsistencies and misuses of the concept of ubuntu (often for political reasons) to defend the case for ubuntu's effective application to forgiveness practices. This deteriorates the impact of ubuntu to the point where it appears to have become an overstated, distant myth. Matolino and Kwindingwi (2013:205) argued, in their article, The end of $u b u n t u$, that a big disjuncture and estrangement developed 'between the natural environs in which we can conceive "ubuntu" to have been a success and the current state of affairs in modern day Africa'. According to Matolino and Kwindingwi (2013):

The narrative hardly addresses the increasingly globalised and sophisticated outlook of its subjects. In an ever-shifting global world the people of the narrative have become less influenced and subject to the grip of the narrative. (p. 198)

The African jurisprudence should be infused and inspired with a restorative nature, not a desire for retaliation and revenge. Haws (2009:1) highlights that 'forgiveness can realise "ubuntu" because it progresses forward toward justice not backward toward vengeance'. A language of forgiveness and reconciliation, based on this paradigm, should correspond to the notion of ubuntu. According to Breed and Semenya (2015:2), 'healthy "ubuntu" can bind people together across the borders of race, colour and gender'.

This communally grounded mindset dispenses retributive principles and in its place provides reparations to victims and rehabilitation to offenders. In this mindset, the idea of retribution and revenge can be abolished as a possible way to forgiveness and reconciliation, 'focusing on adaptation and contextualisation through discussions of "ubuntu," solidarity, hospitality, humanness' (cf. Duncan 2014:2). Forgiveness is not just an act to set unjust people free, but also brings healing in people's hearts and their society and community for the wrong done to them (Bash 2011:loc.1302).

Forgiveness does not mean that people may not defend themselves as an individual, but it does mean that the way they react when they are personally wronged is part of their gratitude that Jesus' embodiment of forgiveness made a difference in their life. Forgiving people are witnesses, within the context of community and society, to God's mercy, love and compassion through Christ (cf. Denton 2016:2). People should be equipped to find common ground that they are, on the one hand, all created in the image of God and share his intended peace, friendship and goodness in Creation. On the other hand, they engage the narrative of the Triune God in seeking unity of communion through grace, forgiveness and reconciliation.

\section{Forgiveness in the church}

The search for peaceful neighbourliness seems to be a critical consideration for the church in modern-day South Africa. Community and society have become overwhelmed by violations of human dignity and violence-driven problems. Christians have a duty to be the voice of forgiveness, and the church, community and society can organise and collaborate to raise awareness of the forgiveness process and promote peaceful neighbour relations. Churches should advance a contextual approach to the forgiveness process and encourage their community to apply forgiveness in their activities to promote the moral improvement of the South African society.

The church should promote justice and forgiveness to enhance the quality of life and dignity of all human beings. According to Strauss (2015:4), human dignity 'should be a natural part of the church's approach of people, but also of its prophetic voice filled with an accepted biblically orientated justice, in society'. Forgiveness in the church entails that 'Christians can forgive transgression and wrongdoing because they are responding in gratitude to God's mercy, loving-kindness and forgiveness through Jesus' death on the cross' (Denton 2016:1). The following principles are essential in describing a forgiving church community:

- The church should be a prophetic witness to the community and society. The church has a duty to be an active agent of forgiveness in the face of $\sin$ and brokenness (Jones 1995:5). Vorster (2011:53) highlights that 'churches should be the voice of the injured by pointing out the injustices in society' and 'examples of repentance and forgiveness'.

- Christians can remind one another within the Christian community to proclaim and to bear witness to God's forgiveness and reconciling love in Christ through the work of the Holy Spirit (cf. 1 Jn 1:9-10). The Spirit enables the church to become a 'carrier' of the forgiving truthfulness of Jesus (1 Cor 12:1-11; Jones 1995:131).

- The Christian community should conduct their prophetic calling and communicate forgiveness via preaching, catechetics, pastoral care, liturgy and mission.

- Forgiveness is a qualified moral virtue and duty, a gift of grace (Bash 2011:loc.2773). It could enhance the wellbeing of every community and society (cf. Eph 2:11-22) if the Christian community contributes their unique gift of forgiveness for the interests of all the others in society.

- Christian leadership should provide Christians in their community and society with effective guidance regarding their role in the interconnectedness between ubuntu principles and the embodiment (personification) of forgiveness. 
The Christian community has to be equipped regarding the message of forgiveness and their servant leadership and prophetic voice of commitment to forgiveness in all spheres of society. Enright (2011:26) argued that the endpoint of the church as a forgiving community is fourfold:

- to help the local congregation incorporate the understanding of and the practical application of forgiveness within the church community as a way to help individuals, families and groups within the church

- to help people see the connection between divine forgiveness and the person-to-person dimension of it, thus possibly reawakening the sense of importance of confession within local churches

- to be a foundation for growth in forgiveness across the world as pastoral workers use the practical ideas to create 'Forgiving Communities' within their congregation, with the commitment, for example, to then make contact with at least one other congregation to help people form their own 'Forgiving Community'

- to begin a dialogue that can be extended in university departments of Theology, Philosophy and Psychology about how to create and sustain 'The Church as Forgiving Community'.

The fundamental reason for focusing on forgiveness in the church should be because forgiveness is one of the indispensable themes in the Bible and a prophetic responsibility to modern-day South Africa. God confronts sin and evil and uncovers our wounds, both those inflicted on us and those we have inflicted on others and ourselves (cf. Jones 1995:146). God's judgment and confrontation with sin and evil not only aims to condemn people but to forgive and to heal wounds (cf. Jn 3:16-21). God's forgiveness and grace guide people to repentance of their transgressions and to forgive others' evil acts and wrongdoing in order to live in harmony within the context of their relationship with God, one another and God's creation. Jones (1995:131) argues that the Holy Spirit 'not only makes particular the universal significance of Christ's forgiveness'; the Holy Spirit also takes the identity of Christ and 'makes it universal through the practices and friendships of the Body of Christ, the Church'.

\section{Conclusion}

This article will hopefully make a positive contribution to the discussion on the invocation and necessity of an integrative and applicable forgiveness process within the complicated and multifaceted (multidimensional) South African society with its realities of crime, poverty, racism, injustice, abuse and so on. The suggestion is made that forgiveness within the Christian doctrine needs to be more carefully situated and embodied in specific habits and practices of Christian life in violence-driven problem areas in South Africa.

What could positively contribute to the modern-day South African community and society involves an applicable forgiveness process that is merged into the ubuntu mindset. In response, South Africans are called to remember their pain and injustice, to repair the brokenness in their community and society and to pursue the repairing of separations in relationships by expressing forgiveness and providing a meaningful alternative in the face of sin and evil. The imago Dei teaches 'the inherent human dignity of all people, which should be respected by fellow human beings and social institutions' (Vorster 2011:47).

Forgiveness is a choice of either a path of bitterness and revenge or to enter a path of freedom as a recovery experience to deal with the pain of injustice. The Bible shows that forgiveness is not only relevant in the God-man relationship but also in interpersonal relationships with other people. Practising forgiveness involves a process of seeking to embody Christian forgiveness that involves the transformation of people's lives, their world and their capability for truthful and honest communion. As a social activity (mindset), ubuntu may enable people to encourage forgiveness in their communities in various ways to promote social cohesion in a country that is polarised by crime and violence.

The task of a constructive form of interconnectedness between the ubuntu principles and the embodiment (personification) of forgiveness is to enable a long-term process framework of productive and mutually respectful interchange. In this regard, forgiveness and the ubuntu principles point towards the importance of the church's prophetic task of presenting healing when people attempt to move on with their lives after painful and traumatic experiences. Forgiveness in this context could be the accomplishment of a process through which injured people triumph over painful or traumatic experiences and express the life-giving ability to transform violence-driven communities into 'forgiving communities'.

\section{Acknowledgements Competing interests}

The author declares that he or she has no financial or personal relationships which may have inappropriately influenced him or her in writing this article.

\section{References}

Bardos, M., Burns, M. \& James, P., 2009, Global restrictions on religion, Pew Forum on religion \& public life, Washington, DC, viewed 06 July 2016, from http://assets. pewresearch.org/wp-content/uploads/sites/11/2009/12/restrictions-fullreport1.pdf

Barry, S., 2009, 'Taking responsibility for reconciliation: A Christian response to the legacy and challenges of the South African Truth and Reconciliation Commission (TRC)', In die Skriflig/In Luce Verbi 43(2), 361-395. https://doi.org/10.4102/ids.v43i2.228

Bash, A., 2007, Forgiveness and Christian ethics, Cambridge University Press, Cambridge.

Bash, A., 2011, Just forgiveness: Exploring the bible, weighing the issues, SPCK Publishing, London. Bonhoeffer, D., 1995, 'Christ's love and our enemies', in G.B. Kelly \& F.B. Nelson (eds.), A testament to freedom: The essential writings of Kelly \& F.B. Nelson (eds.), A testament to freedom: The essential
Dietrich Bonhoeffer, pp. 284-288, HarperCollins, San Francisco, CA.

Breed, G., 2015, 'Finding guidelines on social change in the two-tiered narrative and diakonia in the Gospel of John', HTS Teologiese Studies / Theological Studies 71(2), 1-8. https://doi.org/10.4102/hts.v71i2.2666

Breed, G. \& Semenya, K., 2015, 'Ubuntu, koinonia and diakonia, a way to reconciliation in South Africa?', HTS Teologiese Studies / Theological Studies 71(2), 1-9. https:// doi.org/10.4102/hts.v71i2.2979

Brodie, N., 2016, Religion (they say) is on the rise, Mail \& Guardian, viewed 03 July 2016, from http://mg.co.za/article/2016-03-23-religion-is-on-the-rise-say-researchers

Broodryk, J., 2002, Ubuntu: Life lessons from Africa, Ubuntu School of Philosophy, Indiana University, Bloomington, IN. 
Chuwa, L.T., 2014, African Indigenous Ethics in Global Bioethics: Interpreting Ubuntu, Springer, New York, NY

De Gruchy, J.W., 2011, 'The humanist imperative in South Africa', South African Journal of Science 107(7/8), 804-807. https://doi.org/10.4102/sajs.v107i7/8.804

Denton, R.A., 2014a, 'Exploring biblical reformational theology as a normative perspective for Christian psychology', In die Skriflig/In Luce Verbi 48(1), 1-11. https://doi.org/10.4102/ids.v48i1.1791

Denton, R.A., 2014b, 'Utilising forgiveness to help sexually abused adolescents break free from guilt and shame: A pastoral Gestalt theory', Acta Theologica 34(2), 5-28.

Denton, R.A., 2016, 'Die helende krag van regverdige vergifnis, sonder kondonering van onreg', HTS Teologiese Studies/Theological Studies 72(4), 1-10. https://doi. org/10.4102/hts.v72i4.3265

Duncan, G.A., 2014, 'Inculturation: Adaptation, innovation and reflexivity. An African Christian perspective', HTS Teologiese Studies / Theological Studies 70(1), 1-11. https://doi.org/10.4102/hts.v70i1.2669

Emmons, R.A., 2006, 'Spirtituality: Recent progress', in M. Csikszentmihalyi \& I.S. Csikszentmihalyi (eds.), A life worth living: Contributions to positive psychology, pp. 62-81, Oxford University Press, New York, NY.

Enright, R.D., 2011, 'Psychological science of forgiveness: Implications for psychotherapy and education', Presented at the Conference, Neuroscience and Moral Action: Neurological Conditions of Affectivity, Decisions, and Virtue, July, pp. 1-36, viewed 20 August 2016, from https://www.researchgate.net/ publication/266879605

Hägerland, T., 2014, Jesus and the forgiveness of sins an aspect of his prophetic mission, Cambridge University Press, New York, NY

Hailey, J., 2008, 'Ubuntu: A literature review', A paper presented for the Tutu Foundation, November, pp. 1-26, viewed 23 August 2016, from http://citeseerx. ist.psu.edu/viewdoc/download?doi=10.1.1.459.6489\&rep=rep1\&type=pdf

Haws, C.G., 2009, 'Suffering, hope and forgiveness: The ubuntu theology of Desmond Tutu', Scottish Journal of Theology 62(4), 477. https://doi.org/10.1017/ S0036930609990123

Hunt, J., 2013, Forgiveness: The freedom to let go, Rose Publishing, Torrance, CA.

Jirsa, J., 2004, 'Forgiveness and revenge: Where is justice?', in A. Cashin \& J. Jirsa (eds.), Thinking together. Proceedings of the IWM Junior Fellows' Conference, pp. 1-28, IWM Junior Visiting Fellows' Conferences, Vienna.

Jones, L.G., 1995, Embodying forgiveness: A theological analysis, W.B. Eerdmans, Grand Rapids, MI.

Joubert, Y. \& Grobler, A., 2013, 'The value and extent of religious participation of members of the South African Police Service (SAPS)', HTS Teologiese Studies / Theological Studies 69(1), 1-10. https://doi.org/10.4102/hts.v69i1.1180

Komesaroff, P.A., Kath, E. \& James, P., 2011, 'Reconciliation and the Technics of Healing', Journal of Bioethical Inquiry 8(3), 235-237. https://doi.org/10.1007/ s11673-011-9318-y

Koopman, N.N., 2015, 'Theology and the building of civilizing democracy in South Africa', NGTT / Stellenbosch Theological Journal 55(3-4), 625-639.

Kwamwangamalu, N.M. \& Nkonko, M., 1999, 'Ubuntu in South Africa: A sociolinguistic perspective to a Pan-African concept', Critical Arts Journal 13(2), 24-42. https:// doi.org/10.1080/02560049985310111

Levinas, E., 2000, Difficult freedom: Essays on Judaism, Athlone Press, Baltimore, MD.

Louw, D.J., 2001, Ubuntu and the challenges of multiculturalism in post-apartheid South Africa, Quest XV(1-2), 15-36, viewed 06 July 2016, from http://www.questjournal.net/access_to_volumes.htm

Macaskill, A., 2008, 'Just-world beliefs and forgiveness in men and women', in W. Malcolm, N. DeCourville \& K. Belicki (eds.), Woman's reflections on the complexities of forgiveness, pp. 39-59, Routledge, New York, NY.

Malcolm, W., 2008, 'The timeliness of forgiveness interventions', in W. Malcolm, $\mathrm{N}$. DeCourville \& K. Belicki (eds.), Woman's reflections on the complexities of forgiveness, pp. 275-292, Routledge, New York, NY.

Masci, D., 2015, Christianity poised to continue its shift from Europe to Africa, Pew Research Center, viewed 06 July 2016, from http://www.pewresearch.org/facttank/2015/04/07/christianity-is-poised-to-continue-its-southward-march/

Mashua, M.W., 2016, 'Religion matters', Mail \& Guardian, viewed 03 July 2016, from http://mg.co.za/article/2016-03-24-religion-matters

Matolino, B. \& Kwindingwi, W., 2013, 'The end of ubuntu', South African Journal of Philosophy 32(2), 197-205, viewed 07 July 2016, from https://doi.org/10.1080/0 2580136.2013.817637

McAllister, P.A., 2009, 'Ubuntu-beyond belief in Southern Africa', Sites: A Journal of Social Anthropology and Cultural Studies 6(1), 1-10, viewed 21 August 2017, from $\mathrm{http}: / /$ sites.otago.ac.nz/index.php/Sites/article/download/94/80
Mcllroy, D.H., 2008, 'Towards a relational and trinitarian theology of atonement', Evangelical Quarterly 80(1), 13-32.

Minirth, F.B. \& Meier, P.D., 2007, Happiness is a choice, Baker Book House, Grand Rapids, MI.

Mle, T.R. \& Maclean, S., 2011, 'Ethics, integrity and good governance: The case of South African local sphere government', Journal of Public Administration 46(4) 1364-1383.

Mwambazambi, K. \& Banza, A.K., 2014, 'Four-dimensional conversion for spiritual leadership development: A missiological approach for African churches', HTS Teologiese Studies / Theological Studies 70(3), 1-9. https://doi.org/10.4102/hts. v70i3.1953

Osmer, R.R., 2008, Practical theology: An introduction, Eerdmans, William B. Publishing Company, Grand Rapids, MI.

Pew Research Center, 2010a, Sub-Saharan Africa religion database, viewed 03 July 2016, from http://www.pewforum.org/interactives/africa/country/203/

Pew Research Center, 2010b, Sub-Saharan Africans deeply committed to Christianity and Islam, viewed 04 July 2016, from http://www.pewforum.org/2010/04/15/ sub-saharan-africans-deeply-committed-to-christianity-and-islam/

Ransley, C. \& Spy, T., 2004, Forgiveness and the healing process: A central therapeutic concern, Brunner-Routledge, Hove.

Roberts, C.R. \& Watson, P.J., 2010, 'A Christian psychology view', in E.L. Johnson (ed.) Psychology and Christianity: Five views, pp. 149-178, InterVarsity Press, Downers Grove, IL.

Smith, D.J., 2007, Essays in public theology: Collected essays, Sun Press, Cape Town.

South Africa, 1996, Constitution of the Republic of South Africa, viewed 05 July 2016, from http://www.gov.za/documents/constitution-republic-south-africa-1996

Statistics South Africa, 2012, Census Statistics 2012, viewed 03 July 2016, from http:// www.statssa.gov.za/publications/SAStatistics/SAStatistics2012.pdf

Statistics South Africa, 2016, Community Survey 2016, viewed 05 July 2016, from http://cs2016.statssa.gov.za/wp-content/uploads/2016/07/NT-30-06-2016RELEASE-for-CS-2016-_Statistical-releas_1-July-2016.pdf

Strauss, P.J., 2015, 'Church and state in South Africa and human rights', In die Skriflig/ In Luce Verbi 49(1), 1-6. https://doi.org/10.4102/ids.v49i1.1990

Thesnaar, C.H., 2014, 'Seeking feasible reconciliation: A transdisciplinary contextual approach to reconciliation', HTS Teologiese Studies / Theological Studies 70(2), 1-8. https://doi.org/10.4102/hts.v70i2.1364

Tutu, D., 1999, No future without forgiveness, Doubleday, New York, NY.

Udeani, C.C., 2008, 'Traditional African spirituality and ethics - A panacea to leadership crisis and corruption in Africa?', Phronimos 9(2), 65-72.

Van de Beek, A., 2012, Lichaam en Geest van Christus: De theologie van de kerk en de Heilige Geest, Uitgeverij Meinema, Zoetermeer.

Vorster, J.M., 2001, "n Christelike teorie van menseregte', In die Skriflig 35(1), 1-23. https://doi.org/10.4102/ids.v35i1.542

Vorster, J.M., 2010, 'Calvin and human dignity', In die Skriflig: A Festschrift from the Conventus Reformatus 44(3), 197-213. https://doi.org/10.4102/ids.v44i0.189

Vorster, J.M., 2011, Menswaardigheid, versoening en vergifnis, Potchefstroomse Teologiese Publikasies, Potchefstroom.

Vorster, J.M., 2014, 'Etiese perspektiewe op haatspraak in die lig van die derde gebod Die derde gebod', In die Skriflig/In Luce Verbi 48(2), 1-8. https://doi.org/10.4102/ ids.v48i2.1016

Vorster, J.M., 2015, 'A reformed perspective on the concept of the "common good" and its relevance for social action in South Africa today', In die Skriflig/In Luce and its relevance
Verbi $50(2), 1-9$.

Vorster, N., 2007, Restoring human dignity in South Africa: Christian anthropology in a new dispensation, Potchefstroom Theological Publications, Potchefstroom.

Worthington, E.L., 2009, A just forgiveness: Responsible healing without excusing injustice, InterVarsity Press, Downers Grove, IL.

Worthington, E.L., Greer, C.L. \& Lin, Y., 2011, 'Forgiveness', in T. Clinton \& R. Hawkins (eds.), The popular encyclopedia of Christian counseling: An indispensable tool for helping people with their problems, pp. 134-136, Harvest House Publishing, Eugene, OR.

Van Wyk, J.H., 2014, 'Calvinism, atheism and freedom of religion: A South African perspective', In die Skriflig/In Luce Verbi 48(2), 1-12. https://doi.org/10.4102/ids. v48i2.1721

Van Wyk, J.H. \& Vorster, N., 2012, 'An introduction to the theological politico-ethical thinking of Koos Vorster', In die Skriflig/In Luce Verbi 46(1), 1-10. https://doi. org/10.4102/ids.v46i1.76 